\title{
Analisis Following To Followers Ratio Tiktok Pada \\ 5 Tiktokers Terbanyak Followersnya di Indonesia
}

\author{
Verona Kristiani Suhartina Rawung \\ verona.kristianisr@gmail.com
}

\begin{abstract}
Tik Tok is one of the social media that is currently a trend in Indonesia. TikTok was launched in September 2016 by Zhang Yiming, and was developed using ByteDance's artificial intelligence. Content creators have started using TikTok to post positive content including da'wah. In this study, there are 17 ratios that exist on TikTok social media and are relevant to be used as a medium for measuring the credibility of existing accounts. This study only focuses on calculating the credibility of the Following To Followers Ratio on the 5 Tiktokers with the Most Followers in Indonesia, including: Ria Ricis, Aurelie Hermansyah, Lydora Ginting, Tiara Andini, and Raffi Nagita 1717. This study uses a quantitative exploratory method. The results of this study indicate that Ria Ricis's Tiktoker got the first rank because it has the most followers.
\end{abstract}

\begin{abstract}
ABSTRAK
Tik tok merupakan salah satu social media yang sedang trend saat ini diindonesia. TikTok diluncurkan pada September 2016 oleh Zhang Yiming, dan dikembangkan menggunakan kecerdasan buatan besutan ByteDance. Para konten kreator mulai menggunakan TikTok untuk memposting konten positif termasuk dakwah. Pada penelitian ini terdapat 17 rasio yang ada pada sosial media TikTok dan relevan digunakan sebagai media ukur kredibilitas akun yang ada. Penelitian ini hanya berfokus untuk menghitung kredibilitas Following To Followers Ratio pada 5 Tiktokers Terbanyak Followersnya di Indonesia, diantaranya: Ria Ricis,Aurelie Hermansyah, lydora ginting, Tiara andini, dan RaffiNagita1717. Penelitian ini menggunakan metode eksploratif kuantitatif. Hasil dari penelitian ini menunjukan bahwa Tiktoker Ria Ricis yang mendapatkan peringkat pertama karena memiliki followers terbanyak.
\end{abstract}

Keywords : Credibility Account TikTok ; Social Media Marketing ; Social Media TikTok ; Following To Followers Rasio ; 5 Tiktokers Terbanyak Followersnya Di Indonesia 


\section{PENDAHULUAN}

Saat ini teknologi di Indonesia semakin pesat Social media adalah sebuah media untuk bersosialisasi satu sama lain dan dilakukan secara online yang memungkinkan manusia untuk saling berinteraksi tanpa dibatasi ruang dan waktu. Sosial media menghapus batasan-batasan manusia untuk bersosialisasi, Batasan ruang maupun waktu, dengan media social ini manusia dimungkinkan untuk berkomunikasi satu sama lain dimanapun mereka bereda dan kapanpun, tidak peduli seberapa jauh jarak mereka, dan ttidak peduli siang atau pun malam (“Apa Itu Sosial Media” n.d.).

Membahas mengenai media sosial, salah satu media sosial yang sedang menjadi tren saat ini adalah TikTok. TikTok juga dikenal sebagai Douyin di China, yang secara harfiah berarti 'Teknik musik pendek'.TikTok diluncurkan pada September 2016 oleh Zhang Yiming, dan dikembangkan menggunakan kecerdasan buatan besutan ByteDance. Aplikasi ini menghadirkan special effects yang menarik dan mudah digunakan, sehingga semua orang bisa menciptakan sebuah video yang keren dengan mudah.TikTok kini seakan menjadi aplikasi primadona yang layak dan wajib diunduh oleh semua orang. Akhir-akhir ini, terutama masa pandemi di seluruh penjuru dunia masih terjadi, TikTok sedang digemari oleh seluruh kalangan ("Fenomena Aplikasi TikTok Dan Dampaknya Bagi Masyarakat Di Tengah Pandemi” n.d.)

Keberadaan media sosial TikTok menimbulkan berbagai pro dan kontra khususnya bagi masyarakat Indonesia yang menilai aplikasi tersebut berdampak negatif karena konten-konten yang berisi taritarian dan sejenisnya. Seiring berjalannya waktu, para konten kreator mulai menggunakan TikTok untuk memposting konten positif termasuk dakwah. Media salah satu faktor yang bisa mempengaruhi sikap karena intensitas dalam mengaksesnya maka intensitas mengakses dan sikap keberagamaan menjadi variabel bebas dan terikat dalam penelitian ini ("Institutional Repository UIN Syarif Hidayatullah Jakarta: Pengaruh Intensitas Mengakses Akun Tiktok Dakwah @Basyasman00 Terhadap Sikap Keberagamaan (Survei Pada Followers Tiktok @Basyasman00)" n.d.). Tujuan penelitian ini adalah untuk melakukan uji teoritik mengenai pengaruh dan seberapa besar pengaruh diantara kedua variable yaitu intensitas mengakses dan sikap keberagamaan yang dilakukan survei pada followers 5 akun TikTok ].

Penelitian ini menggunakan metode eksploratif kuantitatif, dan akan menghitung menggunakan rasio-rasio yang ada pada TikTok. Pada penelitian (Permana and Meinarni 2021).menjelaskan bahwa terdapat 17 rasio yang ada pada sosial media TikTok dan relevan digunakan sebagai media ukur kredibilitas akun yang ada. Penelitian ini hanya berfokus untuk menghitung kredibilitas Following To Followers Ratio pada 5 Tiktokers Terbanyak Followersnya di Indonesia, diantaranya: Ria Ricis,Aurelie Hermansyah, lydora ginting, Tiara andini, dan RaffiNagita1717. Tujuan dari penelitian ini adalah mengetahui kredibilitas performa dari akun TikTok 5 Tiktokers Terbanyak Followersnya di Indonesia menggunakan Following To Followers Rasio ("20 Artis TikTok Dengan Followers Terbanyak Di Indonesia 2021 · Pencarian.id” n.d.).

\section{TINJAUAN PUSTAKA}

Kehadiran kehadiran media sosial seakan tidak dapat dilepaskan dari kehidupan remaja karena pada saat ini hampir setiap hari jam menit bahkan detik tidak berhenti untuk update status. Biasanya jejaring sosial digunakan remaja untuk berbicara tentang kehidupan mereka berbicara tentang apa yang mereka lakukan sehari hari bahkan menunjukan eksistensi diri dengan menunjukan kemana mereka pergi atau tempat tempat mereka sukai dan memposting foto-foto. Hal seperti ini sangat lah jelas terlihat peran media sosial dalam pencarian eksistensi bagi remaja. Media sosial kini 
mengubah gaya hidup para remaja, yang biasanya hanya eksis di lingkungan sekitar secara nyata sekarang dengan media sosial remaja sudah dapat eksis hanya dengan memposting foto/Video.

Eksistensi diri dapat dilakukan oleh semua manusia tanpa terkecuali dan juga dapat disaksikan oleh orang lain. Eksistensi diri ada pada setiap diri manusia tanpa mengenal batasan usia, jenis kelamin, pendidikan, status sosial dan lain-lain, selain itu eksistensi diri terbentuk karena adanya dorongan dari dalam individu tersebut dan adanya tuntutan manusia sebagai makhluk sosial. Apabila orang lain menganggap individu eksis, maka keberadaan individu tersebut sudah dianggap dan dapat diperhitungkan oleh orang-orang disekitarnya. Maka dari itu, eksistensi biasanya dijadikan acuan sebagai ajang pembuktian diri bahwa kegiatan atau pekerjaan yang dilakukan dapat berguna dan mendapat nilai yang baik dimata orang lain. begitu juga yang rasakan oleh remaja pengguna aplikasi Tik Tok, mereka akan membentuk konsep diri yang sesuai dengan keingininnya untuk membentuk eksistensi diri kepada orang lain.

Aplikasi TikTok memiliki muatan positif, misalnya sebagai ajang hiburan, satu seni, mengimplementasikan dan mengeksistensi diri untuk memberikan kepuasan bagi dirinya sendiri maupun orang lain, selain itu dengan menggunakan aplikasi Tik Tok penggunannya dapat mengeluarkan kreativitas dan bakat yang dimiliki misalnya seperti bernyanyi,dubbing, membuat konten-konten seru yang unik sampai dapat menjadikan seorang sebagai influencer seperti artis, selebgram, youtuber dan lainnya. Sayangnya popularitas Tik Tok tidak hanya membawa dampak positif saja tetapi membawa dampak negatif juga, yang disebabkan oleh kurangnya konsep diri dari individu itu sendiri, misalnya dalam penggunaan baju yang sexy dan joget dengan goyangan yang erotis dan tidak pantas untuk dilakukan, ironisnya banyak penggunanya khususnya remaja yang mencoba untuk mengikuti hal tersebut, ini dilakukan untuk menjadi pusat perhatian kemudian menjadi viral.

\section{METODOLOGI PENELITIAN}

Penelitian ini menggunakan metode eksploratif kuantitatif, untuk Following To Followers Ratio pada 5 Tiktokers Terbanyak Followersnya di Indonesia, diantaranya: Ria Ricis,Aurelie Hermansyah, lydora ginting, Tiara andini, dan RaffiNagita1717. Dimana metode eksploratif ini merupakan penelusuran, terutama dalam pemantapan konsep yang akan digunakan dalam ruang lingkup yang penelitiannya lebih luas dengan jangkauan konseptual yang lebih besar.

Tujuan Penelitian ini yaitu untuk megetahui Tujuan dari penelitian ini adalah mengetahui kredibilitas performa dari akun TikTok 5 Tiktokers Terbanyak Followersnya di Indonesia menggunakan Following To Followers Rasio ("20 Artis TikTok Dengan Followers Terbanyak Di Indonesia 2021 · Pencarian.id" n.d.). Terdapat beberapa Langkah yang harus dilakukan dalam penelitian ini, untuk menemukan peringkat pertama dalam following to followers yang memiliki performa terbaik. Cara yang harus dilakukan pada penelitian ini yaitu :

- Melakukan Eksplorasi Pada Website Untuk Menentukan Objek yang akan Dianalisa. Ekplorasi ini dilakukan pada beberapa halaman website yang menyediakan informasi mengenai objek yag akan di teliti. Setelah ekplorasi selesai dilakukan, sehingga ditemukan nama-nama tiktokers yang memiliki followers terbanyak di Indonesia yang akan dijadikan objek Analisa. Setekah melakukan eksplorasi pada halaman websoite, maka hal yang dilakukan selanjutnya yaitu mencari nama akun tiktokers yang memiliki followers terbanyak. 
- Menghitung Nilai Rata-Rata Variabe Dari 5 Tiktokers Terbanyak Followersnya di Indonesia.

Pada langkah ini, peneliti menghitung nilai variable following dan followers. Variabel merupakan salah satu komponen penting yang dibutuhkan peneliti dalam sebuah penelitian. Variabel mencakup segala sesuatu yang ditetapkan untuk mendapatkan informasi mengenai hal tersebut hingga bisa ditarik kesimpulannya ("Variabel Penelitian: Pengertian, Jenis, Dan Contohnya | Kumparan.com” n.d.). Untuk menghitung nilai rata-rata dari variabel following dan variabel followers yaitu dengan cara mengambil minimal 10 followers kemudian di hitung sehingga menemukan nilai rata-rata dari masing-masing variabel

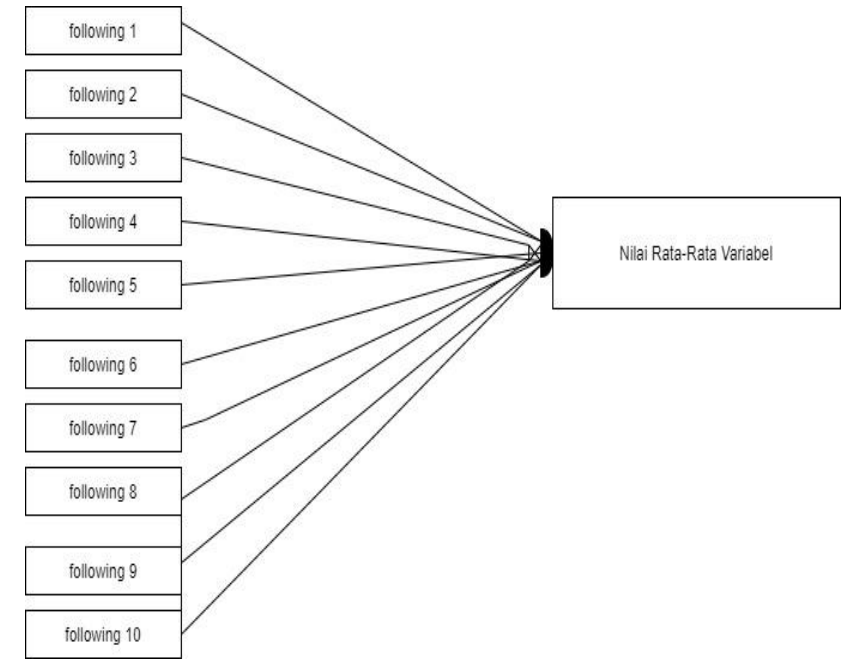

Gambar 1. Analisa Nilai Rata-Rata Variabel

- Menghitung Nilai Kreadibilitas Rasio

Untuk menghitung nilai kredibilitas dari following to followers ratio, peneliti menggunakan cara membagi nilai variabel pertama dengan nilai variabel kedua. Jika following memiliki nilai 100 dan followers memiliki nilai 300, maka cara menghitungnya yaitu $100: 300=0,3$. Dengan begitu nilai dari following to followers ratio adalah 0,3 .

- Menentukan Peringkat Pada Akun Tiktok

Pada langkah terakhir yang dilakukan pada penelitian ini yaitu menentukan peringkat pada masing-masing rasio yang ada. Pada penentuan peringkat perlu melihat karakteristik dari rasio yang di teliti. Jika karakteristik rasio merupakan rendah, maka objek yang memiliki nilai terendah akan mendapatkan angka 5 dan objek yang memiliki nilai tertinggi akan mendapatkan angka 1.

Namun jika rasio memiliki karakteritik tinggi maka objek yang mendapatkan nilai tinggi akan mendapatkan angka 5 dan objek yang mendapatkan nilai terendah akan mendapatkan angka 1. Setelah mendapatkan hasil kredibilitas ratio maka dapat disimpulkan objek yang mana mendapatkan peringkat 1 sampai dengan peringkat 5 . 


\section{Hasil dan Pembahasan}

Akun Tiktok dari 5 Tiktokers Terbanyak Followersnya di Indonesia, diantaranya:

1. Ria Ricis

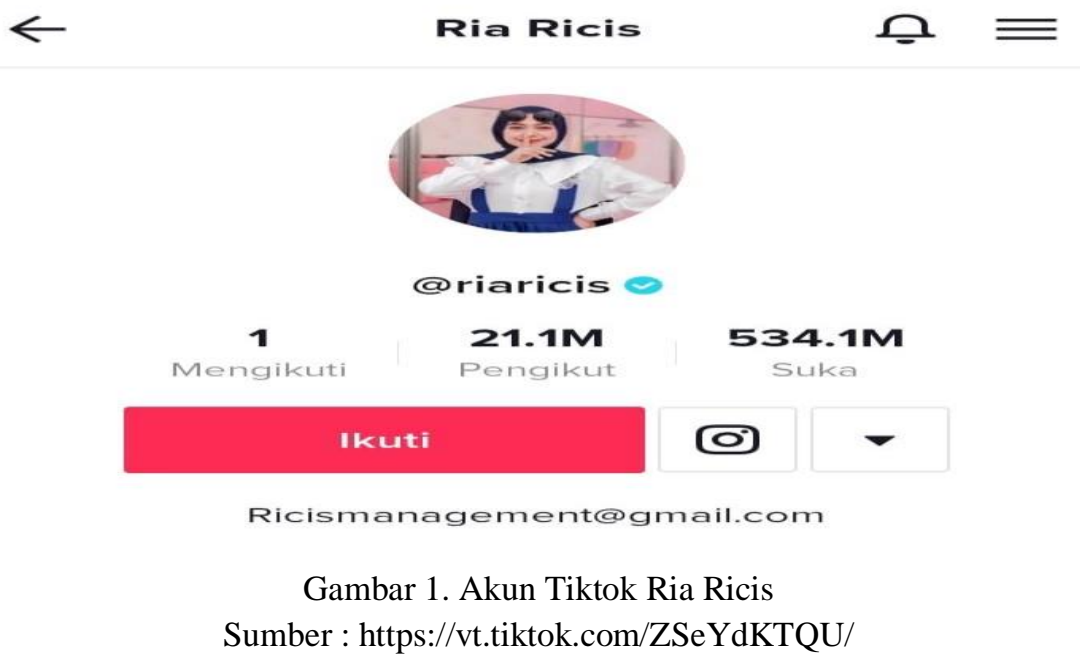

2. Aurelie Hermansyah

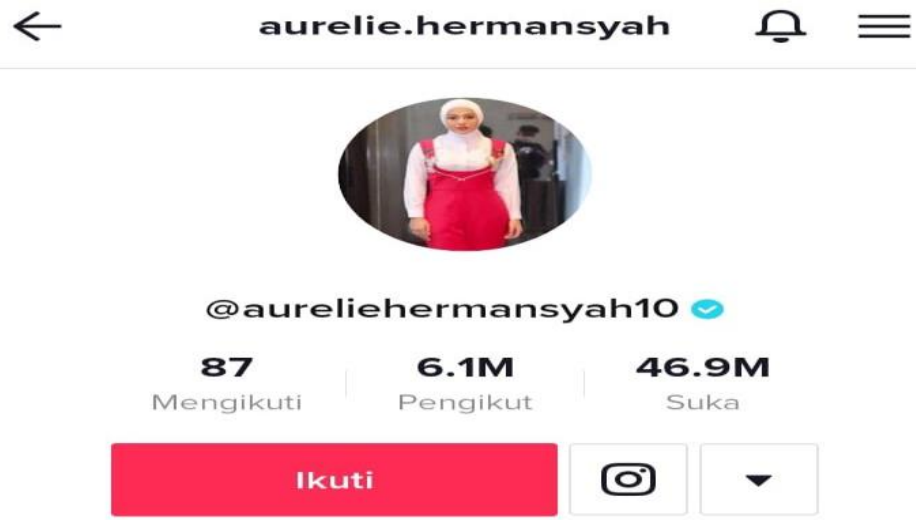

Gambar 2. Akun Tiktok Aurelie Hermansyah

Sumber : https://vt.tiktok.com/ZSeYRjCFx/

3. Lydora Ginting

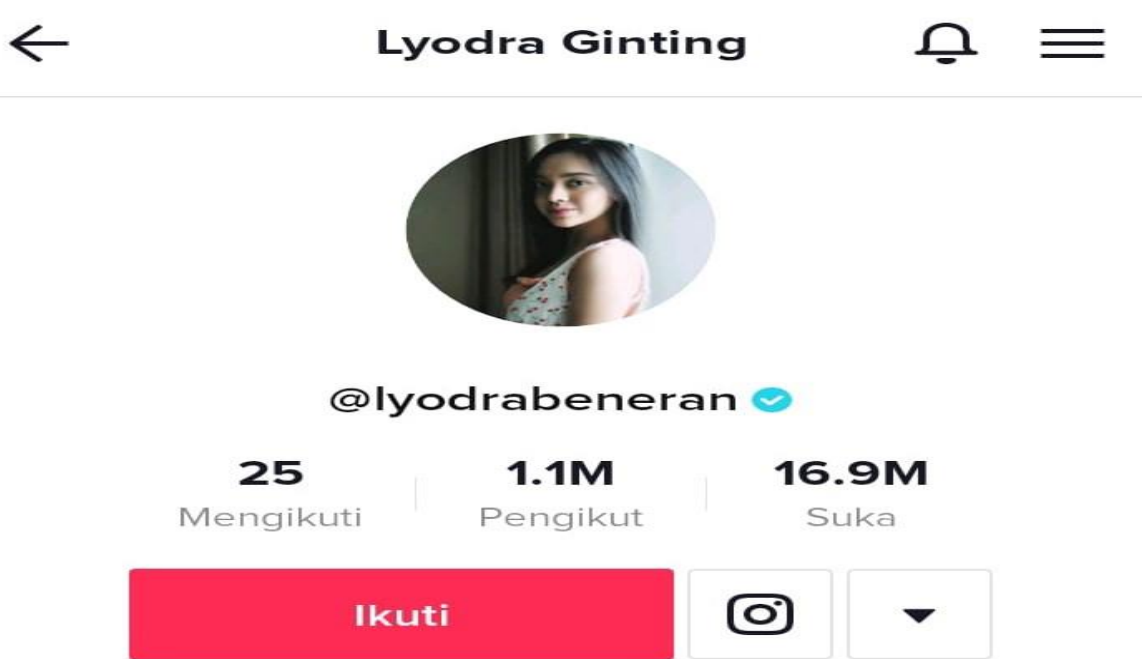

Gambar 3. Akun Tiktok Lyodra Ginting Sumber : https://vt.tiktok.com/ZSeYdGuXN/ 
4. Tiara Andini

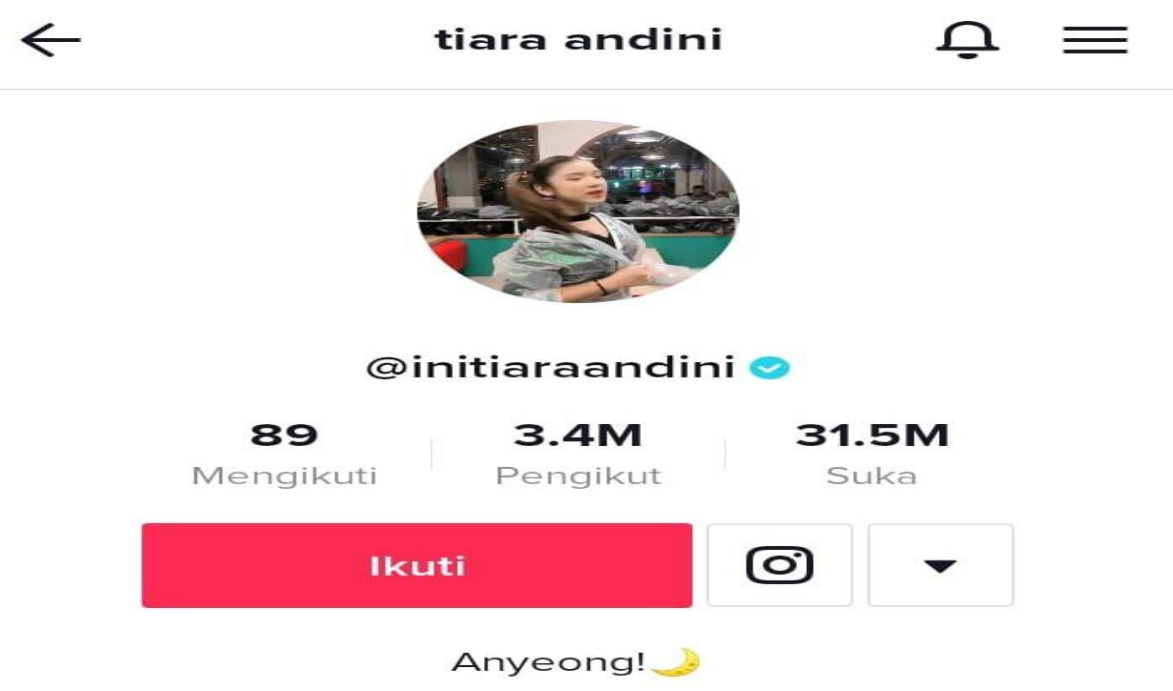

Gambar 4. Akun Tiktok tiara andini

Sumber : https://vt.tiktok.com/ZSeYdtNA7/

5. RaffiNagita1717

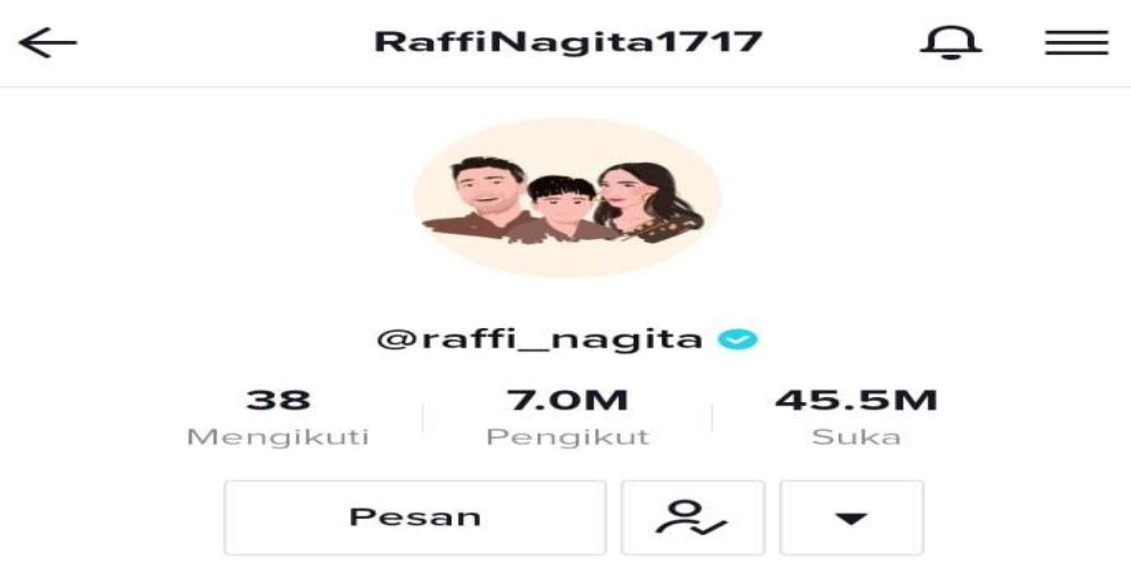

Gambar 5. Akun Tiktok RaffiNagita1717

Sumber : https://vt.tiktok.com/ZSeYRSsyK/

Dari kelima akun Tiktok 5 Tiktokers terbanyak followersnya di Indonesia, peneliti menemukan nilai dari masing-masing variabel yang ada untuk menghitung rasio following to followers dari setiap akun. Pada akun TikTok terdapat 7 variabel, diantaranya yaitu :

1. Likes

2. Followers

3. Following

4. Video Likes

5. Video Comments

6. Video Share

7. Video Views 
Dari ketujuh vriabel tersebut peneliti hanya focus untuk menemukan hasil dari 2 variabel, yaitu :

1. Following

2. Followers

Dari kedua variabel tersebut kemudian dianalisa sehingga menemukan nilai rata-rata dari variabel following dan variabel followers . Untuk menghitung nilai rata-rata dari variabel following dan variabel followers yaitu dengan cara mengambil jumlah following dan followersnya kemudian di hitung sehingga menemukan nilai rata-rata dari masing-masing variabel. Berikut merupakan tabel nilai ratarata dari masing-masing Tiktokers di Indonesia, yaitu:

Tabel 1. Analisa Nilai Rata-Rata Nilai Variabel following dan followers

\begin{tabular}{|} 
Akun TikTok Ria Ricis \\
\begin{tabular}{|c|c|c|}
\hline No & Following & Followers \\
\hline 1 & 1 & 21.100000000 \\
\hline
\end{tabular}
\end{tabular}

Tabel 2. Analisa Nilai Rata-Rata Nilai Variabel following dan followers Akun TikTok Aurelie Hermansyah

\begin{tabular}{|c|r|c|}
\hline No & Following & Followers \\
\hline 1 & 87 & 6.100000000 \\
\hline \multicolumn{2}{|c|}{ Sumber : Pengolah Data Excel } \\
\hline
\end{tabular}

Tabel 3. Analisa Nilai Rata-Rata Nilai Variabel following dan followers

Akun TikTok Lydora Ginting

\begin{tabular}{|c|r|c|}
\hline No & Following & Followers \\
\hline 1 & 25 & 1.100000000 \\
\hline \multicolumn{3}{|c|}{ Sumber : Pengolah Data Excel } \\
\hline
\end{tabular}

Tabel 4. Analisa Nilai Rata-Rata Nilai Variabel following dan followers Akun TikTok Tiara Andini

\begin{tabular}{|c|r|c|}
\hline No & Following & Followers \\
\hline 1 & 89 & 3.400000000 \\
\hline \multicolumn{3}{|c|}{ Sumber : Pengolah Data Excel }
\end{tabular}

Tabel 5. Analisa Nilai Rata-Rata Nilai Variabel following dan followers Akun TikTok RaffiNagita1717

\begin{tabular}{|l|r|l|}
\hline & Following & Followers \\
\hline 1 & 38 & 7.000000000 \\
\hline
\end{tabular}

Sumber : Pengolah Data Excel 
Setelah menghitung nilai rata-rata tersebut, maka akan menemukan hasil akhir nilai rata-rata dari variabel following dan followers.

Tabel 6. Nilai Variabel Pada Akun TikTok 5 TikTokers Terbanyak Followersnya di Indonesia

\begin{tabular}{|c|r|r|r|r|r|}
\hline Variabel & Ria Ricis & aurelie.hermansyah & \multicolumn{1}{|c|}{$\begin{array}{l}\text { Lydora } \\
\text { Ginting }\end{array}$} & tiara andini & RaffiNagita1717 \\
\hline Following & 1 & 87 & 25 & 89 & 38 \\
\hline Followers & 21.10000000 & 6.10000000 & 1.10000000 & 3.40000000 & 7.000000000 \\
\hline
\end{tabular}

Sumber : Pengolah Data Excel

Pada akun TikTok terdapat 17 rasio yang relevan digunakan untuk mengukur kredibilitas pada masing-masing akun. Namun pada penelitian kali ini hanya berfokus untuk menghitung Following to Followers Ratio. Untuk menghitung kredibilitas dari masing-masing akun TikTok setiap TikTokers, peneliti menghitung dengan cara : variabel 1 akan dibagi dengan variabel 2, sehingga ditemukan hasil analisisa dari rasio tersebut.

Tabel 7. Hasil Perhitungan Rasio Akun TikTok

\begin{tabular}{|c|c|c|c|c|c|}
\hline NO & Ria Ricis & aurelie.hermansyah & Lydora Ginting & tiara andini & RaffiNagita1717 \\
\hline & & & & & \\
1 & 0.047393365 & 14.26229508 & 22.72727273 & 26.17647059 & 5.428571429 \\
\hline
\end{tabular}

Sumber : Pengolah Data Excel

Following to Followers Ratio memiliki karakteristik yang tinggi, artinya semakin tinggi nilai yang dihasilkan maka semakin baik kredibilitas dari performa akun tersebut. Untuk memberikan peringkat pada masing-masing TikTokers, peneliti memberikan angka 5 kepada TikTokers yang mendapatkan nilai tertinggi dan angka 1 untuk TikTokers yang mendapatkan nilai terendah. Berikut merupakan tabel urutan nilai yang dihasilkan oleh masing-masing TikTokers.

Tabel 8. Nilai Rasio Tiktok 5 TikTokers Terbanyak Followersnya di Indonesia.

\begin{tabular}{|c|c|c|c|c|}
\hline Ria Ricis & aurelie.hermansyah & $\begin{array}{l}\text { Lydora } \\
\text { Ginting }\end{array}$ & tiara andini & RaffiNagita1717 \\
\hline 1 & 3 & & 5 & 2 \\
\hline
\end{tabular}

Sumber : Pengolah Data Excel

Dari Tabel Nilai Rasio Akun TikTok 5 Tiktokers Terbanyak Followersnya di Indonesia dapat simpulkan bahwa akun TikTok Tiara Andini mendapatkan nilai tertinggi untuk rasio Following to Followers . Sedangkan akun TikTok Ria Ricis mendapatkan nilai terendah untuk rasio ini. Jadi, pada penelitian ini Tiara Andini memiliki kredibilitas performa yang lebih baik dibandingkan dengan Tiktokers yang lainnya. 


\section{Daftar Pustaka}

“20 Artis TikTok Dengan Followers Terbanyak Di Indonesia 2021 · Pencarian.id." n.d. Accessed October 29, 2021. https://pencarian.id/tiktok/20-followers-tik-tok-terbanyakdi-indonesia-2021/.

“Apa Itu Sosial Media.” n.d. Accessed October 29, 2021. http://www.unpas.ac.id/apa-itusosial-media/.

“Fenomena Aplikasi TikTok Dan Dampaknya Bagi Masyarakat Di Tengah Pandemi." n.d. Accessed October 29, 2021.

https://yoursay.suara.com/kolom/2021/07/05/105553/fenomena-aplikasi-tiktok-dandampaknya-bagi-masyarakat-di-tengah-pandemi.

"Institutional Repository UIN Syarif Hidayatullah Jakarta: Pengaruh Intensitas Mengakses Akun Tiktok Dakwah @ Basyasman00 Terhadap Sikap Keberagamaan (Survei Pada Followers Tiktok@Basyasman00).”n.d. Accessed October 29, 2021. https://repository.uinjkt.ac.id/dspace/handle/123456789/57652.

Permana, I Putu Hendika, and Ni Putu Suci Meinarni. 2021. "Ratio Analysis on Tiktok (Social Media) for Qualitative Research Using Explorative Methods." Jurnal Ekonomi \& Bisnis JAGADITHA 8 (1): 30-38. https://doi.org/10.22225/JJ.8.1.2944.30-38.

"Variabel Penelitian: Pengertian, Jenis, Dan Contohnya | Kumparan.com." n.d. Accessed November 13, 2021. https://kumparan.com/berita-hari-ini/variabel-penelitianpengertian-jenis-dan-contohnya-1ul9vdTWwAS. 